\title{
Managing the Environment for Development and to Sustain Pro-poor Growth
}

\author{
Stephen Bass and Paul Steele*
}

\author{
1 The environmental challenge facing Asia \\ 'Without fuelwood we can't even boil water' \\ (Poor woman in Murad Dhand, Pakistan) ${ }^{1}$
}

Asia's rich environmental management traditions sustained its people for centuries. Practical examples include the rice terraces of Indonesia and the Philippines and common property management of Japanese inland fisheries. Some of the greatest Asian thinkers - the Buddha, Confucius and Gandhi - had a profound appreciation of the dependence of people on the natural world. Perhaps such traditions, in part, explain why the Asian public is more concerned about current environmental impacts on health and well-being than people in any other region (Environics International 2002). In the early stages of Asia's drive for economic development, Asian environmental traditions were challenged by economic development models that promoted the exploitation of natural resources for export. Forests were cleared, first for high-value hardwoods and then for tea, coffee and rubber. Mines were developed in previously remote areas.

Environmental change accelerated with rapid agricultural and industrial growth in the twentieth century, becoming more extreme in recent years. Asian agricultural production rose 62 per cent from 1990 to 2002. Forests were cleared rapidly, in part to make way for food production - Indonesia alone lost 1.7 million ha a year of forests during the 1990s. Large areas were irrigated for food production, with high amounts of water and agrochemicals being applied. Asian industrial production rose 40 per cent from 1995 to 2002, compared with 23 per cent globally. As in other regions that experienced industrial revolutions, early industrial developments have involved highly polluting industries. Further developments constantly generate new types of environmental burden, e.g. the heavy metal hazards from 'e-waste' (computers, phones, televisions etc.), one of the fastest growing sources of waste (UNEP 2004; World Bank 2005a).

Asian urbanisation, the fastest in the world, is posing massive environmental challenges. Today, most of the world's mega-cities are in Asia, and so also are the world's biggest slums. By 2020, Asia's urban population is projected to double to 2.2 billion from a little over 1 billion in 1990, and nearly half of Asia's population will live in cities (United Nations Secretariat 2002/3). Water supply, housing, wastewater treatment, solid waste management and transport infrastructure already cannot keep pace. For example, municipalities will face a more than tenfold increase in solid waste burdens by 2025 (with China, Indonesia and the Philippines facing the largest increases). Pollution may reach intolerable levels: already, eight of the world's ten most polluted cities are in China, where 3-6 million life-years are lost each year from pollution (World Bank 2005a). Despite having the fourth largest fresh water reserves in the world, the Ministry of Water Resources states that more than 400 Chinese cities, including the capital, face severe water shortages and people are being forced to migrate because of lack of water (Ramirez 2005).

\section{Such dynamics have brought about enormous} benefits through fuelling the Asian economies and supporting Asian livelihoods. Many development indicators have directly improved as a result - notably 
gross domestic product (GDP), exports, food security, nutritional status, employment and levels of poverty.

However, these changes are reaching unprecedented levels, increasing the severity of four major environmental problems, which may themselves undermine growth and poverty reduction:

1 Decline in quantity or quality of natural resources such as fisheries or soils - which threatens many livelihoods and economic activities, and thus growth

2 Degradation of fundamental ecosystem processes, e.g. natural cycling of water and nutrients, and biological dynamics such as pollination - which threatens all livelihoods and most economic activity

3 Increased climate-related environmental hazards such as floods and droughts - which imposes major costs to life and property

4 Water and air pollution - which damages both health and infrastructure.

Environmental problems are increasingly felt at the regional level. Transboundary resources are often managed unsustainably, e.g. the diminishing fish stocks of the South Pacific or Bay of Bengal; risks to clean air from Indonesian forest fires or East Asian sand and dust storms; and pollution in shared rivers (e.g. the Indus, Mekong and recently, the Songha river where a toxic benzene spill threatens Russia) Cross-border trade may cause overexploitation of timber or wildlife (e.g. in South-east Asia and East Asia). Growing demands by the region's growth centres for resources such as timber, metals and oil are putting other regions under increasing environmental pressure. Regional hazards are also emerging, such as floods and droughts, and animaltransmitted (zoonotic) diseases such as Avian bird flu and severe acute respiratory syndrome (SARS).

Asia has also progressed in some areas of environmental management. Exposure to water pollution and indoor air pollution has, in general, fallen across the region as investment in clean water and electricity has improved. Safe drinking water now reaches a majority of the population in South Asia increasing more rapidly over the last decade than in any other region. Many Asian countries have phased out or banned the most dangerous pesticides. Energy efficiency has improved rapidly, particularly in China.
Re-use of waste products is increasingly handled at the regional level, with waste reprocessing a rapidly growing industry in China. The increase in Asian land area officially protected for biodiversity (up to 7.6 per cent by 2003) is an overlooked environmental success story - even if there is often much to be done to ensure local poor people benefit. Yet most environmental trends remain negative, and more poor people are suffering from them.

There are many promising political, social and economic processes in Asia that are driving pro-poor environmental outcomes:

- Poor people themselves have organised to demand better access to natural resources and improved environmental services - and subsequently to manage resources sustainably and establish improved relations with the authorities. Sometimes this has been done in collaboration with the government - as with the 89,000 forest protection committees in India, and 13,000 forest user groups in Nepal. Neighbourhood groups in the slums of South Asia have organised their own sanitation schemes on massive scales, at costs far lower than those provided inefficiently by municipalities.

- Asia's private sector, as the engine of growth, can play a vital role in responding to environmental challenges, and is already responding with real leadership and innovation. Japan's auto industry has sought to lead the world in low emission vehicles. Asian companies are rapidly adopting environmental management systems, aiming to meet international standards; 40 per cent of companies with the global environmental standard ISO-14001 are from over 100 countries in Asia.

- Asia's vibrant civil society has mobilised to press government to manage natural resources wisely, with especially significant impacts in India and the Philippines. In many countries, faith groups are increasingly involved in environmental debate. The media in many countries are increasing their coverage of environmental issues. And judicial activism, notably in India, has been driving better implementation of government environmental policies through increasing both supply and demand for environmental justice.

- Asian governments are increasingly promoting better care of the environment: decentralising control over natural resources; entering 


\begin{tabular}{lc}
\hline Table $\mathbf{1}$ Asia - percentage shares of wealth, $\mathbf{2 0 0 0}$ & \\
\hline Human and institutional capital & 54.6 \\
Produced capital & 22.8 \\
Natural capital & 22.6 \\
Of which Subsoil & 21.1 \\
$\quad$ Land & 73.1 \\
$\quad$ Forests & 5.8 \\
\hline
\end{tabular}

Where is the Wealth of Nations?, Washington DC: World Bank (2006).

management agreements with resource users; and promoting clean technologies through fiscal instruments. The resource intensity of consumption patterns is being addressed, e.g. Japan's 'Basic Law for a Recycling-Based Society' and its 'Reduce, Reuse and Recycle (3Rs) Initiative' began the trend, and today the Chinese government is exploring ways to develop a 'Circular Economy' - recently committing to generate 15 per cent of China's power from renewable sources by 2020 (up from 7 per cent).

The 5th Asian Ministerial Conference on Environment and Development has concluded that 'long-term, effective poverty reduction requires that the natural environment be protected'. Held in Seoul in 2005, it called for pro-poor 'Green Growth', requiring significant governance, policy and system changes, supported by international partnerships. This article addresses three questions that are central to achieving this bold vision:

1 How can environmental assets continue to contribute to pro-poor growth, especially in lowincome countries in Asia?

2 How can pro-poor environmental improvements be made, and how can Asia's development partners assist?

3 How might environmental degradation undermine Asia's growth, and particularly affect poor people?

\section{How can environmental assets continue to support pro-poor growth, especially in low. income countries in Asia?}

'Water is for us what oil is to the Arabs' (King Wangchuck of Bhutan)2

Natural assets, such as fertile soils, rivers, forests, fisheries and mineral deposits, account for a very significant proportion of national wealth in Asia. Together, they are worth almost as much as the value of man-made assets such as infrastructure. The figure is typically higher for lower income countries, i.e. 25 per cent in South Asia, compared with 21 per cent in East Asia. Indeed, natural capital is the main asset of many of Asia's poorer countries (e.g. 64 per cent in Bhutan).

The historical trend of using natural resources for growth is continuing. Lao PDR, Bhutan and Nepal are developing their water resources to generate hydropower exports to their neighbours. While it remains controversial, the Nam Theun 2 hydropower project in Lao PDR may generate US $\$ 2$ billion in export revenue to Thailand over 25 years. Indonesia has used its oil and mineral wealth to diversify its economy, while Timor Leste sees its rich oil and gas resources as its main driver of growth. Nature tourism is a growing sector in Sri Lanka, Nepal, Kyrgyzstan and Thailand. For example, tourism provides 37 per cent of income in Chiang Mai, Thailand where forest trekking is popular (Thailand Environment Monitor 2004)

The challenge is to use this natural wealth carefully, to (1) generate growth and (2) enable the poor to benefit from this growth, while (3) sustaining the resource base and its continued capacity for propoor growth. There are two main ways in which natural resources can contribute to pro-poor growth:

1 National economic growth, which creates jobs and adds to total income and government revenues which can be used for pro-poor purposes.

2 Development of small- and medium-scale enterprises, through use of forests, fisheries and other natural resources owned and managed by primary producers and processors of natural resources. 


\subsection{How can natural resources drive pro-poor national economic growth?}

For natural resources to sustain pro-poor growth, their extraction should not be subsidised, processing should add real value, the poor must not be harmed by the extraction, and profits must be taxed and used for pro-poor spending. These objectives are not always mutually compatible and there are some difficult choices (DAC/ENVIRONET 2005):

- Avoid subsidising large-scale resource extraction. Many countries lose money from subsidised exploitation, such as by loss-making state firms (e.g. Sri Lanka's state timber corporation), subsidies to government joint ventures (e.g. the Pacific tuna processing industry), large tax write-offs (e.g. Indonesia's timber industry), permitting excessive logging (e.g. Cambodia) or land conversion (shrimp farming Bangladesh, Vietnam). This leads to 'boom and bust': natural capital is asset-stripped, and low resource prices encourage excessive, inefficient processing, which eventually destroys the viability of the industry. The key is to reduce incentives for overexploitation, notably by dismantling subsidies that harm the poor and the environment.

- Increase the value added by a competitive resource industry. With declining terms of trade for primary commodities, successful businesses have invested in technologies that enable increasingly sophisticated processing. Asian timber producers, for instance, once exported sawn- or roundwood, but now export furniture and mouldings. There is broad consensus that the aggregate worth to the economy of further processing is maximised by promoting competitive industry, i.e. without perverse subsidies such as artificially low log prices and log/rattan export bans. Access to technologies and markets is key, as are capacities to help set and meet appropriate international standards

- Ensure that natural resource extraction does not harm neighbouring people but, preferably, supports their development. Many large-scale commercial mining, timber and hydropower investments can come to dominate remote areas with often poor and/or minority populations. They may compete with subsistence harvesters, for whom there is usually little legal recognition. Harm can be avoided and preferably opportunities realised - by careful zoning, local hiring and procurement policies, management agreements, and earmarking some of the profits for local level investments. Several corporate-community forestry partnerships in India and Indonesia offer good examples (Mayers and Vermeulen 2001).

- Allocate natural resource revenue towards pro-poor growth. While some governments have failed to invest their natural resource wealth in pro-poor growth - and thus fall under the 'resource curse' - others have allocated natural resource revenues to poverty-reducing investments. Some have earmarked specific natural resource revenues (notably mineral and forest revenues) to the local administration or local people, as in some mining concessions in the Philippines.

\subsection{How can natural resource-based small and medium enterprises (SMEs) lift people out of poverty?}

Job creation is one of Asia's biggest challenges, and many new jobs will continue to be in the SME sector. To lift themselves out of poverty, poor people will wish to use their major assets - usually natural resources - and aim to add as much value as possible. They may need to group into associations, to help them negotiate better terms and improve the efficiency of environmental asset management. Past attempts at forming producer cooperatives around subsidised inputs, such as in fisheries, have often failed due to political interference and elite capture with the inputs not reaching the poor. A more successful approach is to provide an enabling business environment through secure resource rights, support for common property management, improved access to markets and transport, streamlined regulations and technical support. This is an area for further development: since they tend to be dispersed, natural resource-based SMEs are challenging to support, and difficult to regulate for their environmental impact.

\subsection{How can natural resource conservation benefit poor people?}

Loss of natural resources can impose high economic and social costs. Thus some Asian countries have limited the extraction of key land and sea resources, as well as introducing completely protected areas where extraction is forbidden (such as national parks). These often represent significant conservation developments. But in some cases these have been introduced at high social costs for poor people, who may suffer from blanket harvesting restrictions, as in most national parks. Protected areas can be managed in ways which ensure that neighbouring poor people still receive substantial benefits, and are 
compensated for any loss of existing natural resource use rights. Nature tourism is a fast-growing industry with the potential to provide revenues and employment for poor residents, as well as to preserve ecosystem services.

\section{How might environmental degradation undermine growth and particularly affect poor people?}

'Rapid economic growth has exerted considerable pressure on the environmental sustainability of the region and ... could have an adverse effect on achieving sustainable development' (ESCAP 2005)

Asia's rapid growth is, in some cases, being directly undermined by environmental degradation. In Pakistan, 16 per cent of the land is subject to salinisation resulting from excessive water application, with similar scales of this problem occurring in the Central Asian countries. The irrigation mismanagement in Pakistan costs over US\$200 million per year in reduced food yields (DFID/EC/UNDP/World Bank 2002). In western India, groundwater pumping has enabled agricultural intensification, but water tables quickly dropped from $10-15 \mathrm{~m}$ below ground in the 1970 s to $400-450 \mathrm{~m}$ by the 1990s. In many areas, wells have been abandoned and entire villages have become deserted (Roy and Shah 2002). Shrimp farming has declined in some countries, due primarily to pollution and weak environmental controls; resulting disease caused Asia's shrimp industry losses of over US\$1 billion in the 1990s. Marine overfishing has also undermined economic returns. In the Gulf of Thailand, the average hourly catch has fallen almost ten times from $250 \mathrm{~kg} / \mathrm{h}$ in 1961 to $18 \mathrm{~kg} / \mathrm{h}$ in 1999. Such environmental damage can foment social and political unrest. South Korea saw over 70 antipollution protests in the 1990s (Far Eastern Economic Review 1990). China has faced rural unrest because of increasing pollution.

Investing Asia's drawdown of natural capital in other sectors of the economy can avoid 'boom and bust'. This is particularly the case of minerals and other non-renewable resources which, by definition, are declining with extraction. It is clear that, if natural capital is simply liquidated as consumption, then it will not lead to sustained improvements to the economy. If, however, profits from natural capital extraction are invested in physical capital (e.g. infrastructure) and human capital (e.g. education) to drive further growth, they might make a sustained contribution to improved welfare. Where there is a windfall natural resource gain, such as a rapid oil price rise, this can be set aside in a special saving account. This in itself can be beneficial environmentally if future investments in physical and human capital lead to more efficient resource utilisation, thus reducing further pressure on the resource base. Timing is crucial in shifting from pure resource extraction to resource management and diversified income sources, before it is too late and the resource collapses. In many cases, the switch has not been made in time - such as gold mining in Kyrgyzstan, oil and gas in Indonesia, and some Asian timber enterprises and fishing fleets.

But there are limits to how much draudown of natural capital is economically desirable. Natural capital in Asia is already declining dramatically in both quality and quantity, while manmade and human capital continue to grow. Fisheries are depleted, soils eroded and made saline, aquifers dry up, and forests are denuded. These impacts are significant enough to reduce gross national savings by almost one-third in China, the Philippines and Cambodia; by almost onehalf in Mongolia and Malaysia and by nearly 90 per cent in Indonesia (World Bank 2005b). In addition, there are certain ecosystem processes which are critical for their life-supporting services, notably nutrient recycling, air and water purification, pollination and other biological mechanisms. Loss of this 'critical natural capital' is irreversible and represents a significant threat to the long-term welfare of the human race. Yet, globally, the Millennium Ecosystem Assessment (MEA) has identified that 60 per cent of environmental services (particularly fresh water, air and water purification, climate regulation and pest regulation) have been degraded (Millennium Ecosystem Assessment 2005).

Most poor people in Asia, particularly women, are dependent on natural resources for their livelihoods, but suffer from inadequate access and declining resource quality. Most of Asia's rural poor depend on agriculture, for which access to fertile soil and predictable water supplies is essential. Yet 28 per cent of Asia's land is already degraded and water tables are declining (FAO 2004). World Bank studies in China, Cambodia, Lao PDR and Vietnam suggest that there is a strong overlap between highly degradable land and where the poor live (World 
Bank 2005b). People without access to secure land are, perhaps paradoxically, even more dependent on a wide range of natural resources, as they cannot raise financial capital - and women are disproportionately dependent (Jodha 1990). In West Bengal, three times as many women as men are involved in gathering non-timber forest products; processing is done entirely by women; and twice as many women as men are involved in their marketing (Ford Foundation 1998). Fisheries are the key resource for more poor people in Asia than in any other region (Briones et al. 2004), notably in Bangladesh, India, Indonesia and along the great Mekong River, and many farm households augment their food supplies and incomes by fishing (UNEP 2002).

Many poor people in Asia are exposed to environmental health risks and hazards - both the traditional risks of dirty air and water, but also new risks from zoonotic diseases such as bird flu. There have been major environmental health improvements over the last decades, with 80 per cent of people in low-income Asian countries now having access to improved water sources. However, access to sanitation remains much lower at 44 per cent - partly explaining why water pollution remains a significant problem: faecal coliforms in Asian rivers are 50 times the World Health Organization's (WHO) safe maximum (World Bank 2005b). In South Asia, the environmentally caused disease burden is now greater than that from malnutrition (20 per cent, compared with 15 per cent). Many women and children suffer particularly from indoor air pollution (from dirty cooking fuels used in confined spaces), causing up to 1 million premature deaths each year across Asia. Young children and poorly educated women in poor households in Bangladesh suffer four times as much from indoor air pollution as men in higher income households (Das Gupta et al. 2004). Animal health and human health are becoming increasingly linked in Asia, as people and livestock come into closer contact with wildlife when they move into new areas and intensify agricultural production. Wildlife acts as a 'pool' from which pathogens can emerge, as with avian bird flu and possibly SARS and HIV/AIDS.

Environmental changes have exacerbated Asia's high vulnerability to disasters - and this will increase with climate change. Asia has always experienced wide climatic variation. Buildings, livelihoods and social networks have adapted to cope with natural events. Management of normal floods has been integral to the fishing and farming livelihoods of poor people in Bangladesh and Cambodia. However, these natural events are now becoming more frequent and extreme, leading to more lives lost, more property destroyed and more conflict. In China, natural disasters are now the main direct cause of people falling back into poverty. The poor tend to suffer most, as they live in the most vulnerable areas, e.g. many slum dwellers live on land which is highly vulnerable to environmental hazards such as landslides, pollution and floods. Such vulnerabilities are exacerbated by damage to protective environmental assets, such as coral reefs, coastal mangrove forests and riverine wetlands, which increase exposure to floods - as illustrated in some areas by the devastating tsunami.

Asia includes several larger countries like China and India that are increasingly significant emitters of greenhouse gases. It is also the continent that will experience some of the greatest adverse impacts of climate change, which will affect millions of people in almost all countries. Asia already faces 90 per cent of all climate-related disasters in the world, at a cost of half a million lives each year. Many development assistance investments have recently been shown to be vulnerable to climate change (OECD 2004). A further $2^{\circ}$ rise in temperature is expected to cut farmers' incomes by 25 per cent (DFID 2004). There is an urgent need to balance energy provision with less pollution, and with investment in adapting land use, infrastructure and other systems to climate change (especially in the vulnerable agricultural drylands of India and China, and the fragile coastal zones in Bangladesh and the South Pacific).

As Asian countries grow and trade increases, the world economy's environmental impact ('footprint') becomes heavier, with impacts felt well beyond the main centres of growth. For example, China is now responsible for one-half of the global cement consumption; one-third of coal and steel use, and is the biggest importer of timber. This boosts the revenues of resource-producing countries in the region and beyond, but also increases the rate of resource depletion and carries significant environmental risk such as increased pollution, land degradation and climate change. ${ }^{3} \mathrm{~A}$ similar picture can be painted for large urban centres which obtain many of their supplies from far away, at significant 
environmental costs on the remote ecosystems on which their continued growth depends. The next ten years are likely to witness significant increases in consumer demand in Asia - in China alone it is expected to rise to the equivalent of four more 'USAs' (ADB 2005). Added to the already high, and increasing consumer demand in the West, pressures on the world's natural resource base are also set to increase exponentially, unless rising commodity prices, increasing consumer awareness of 'footprints', and improved policies and market instruments start to dismantle predominant high-input/low-efficiency/ high-waste production processes.

\section{How can pro-poor environmental improvements be made, and how can Asia's development partners help?}

The global market for environmental goods and services is over $\$ 600$ billion in 2005. Asia Pacific accounted for $\$ 37$ billion of this total, but its growth is the fastest in the world, with the market expected to triple by 2015' (ADB 2005)

There is growing agreement that pro-poor environmental change is urgently needed - and moreover, emerging consensus about how to achieve it. The analysis above points to three key areas for improvement:

\section{Institutions and governance \\ 2 Investment \\ 3 International partnerships.}

Institutional and governance changes are key to addressing natural resource management and pollution. Pollution is, in part, a governance issue, when there are few private incentives to protect public assets. While simple point-source pollution problems can be tackled by technological solutions, not all environmental problems can be dismissed by assuming that technical fixes will become available. On the one hand, investments are needed in Asian science, technology and innovation systems to generate effective technology. On the other hand, the underlying causes of many broader-scale environmental problems arise primarily from the political, economic and social systems that drive existing production and consumption patterns. For example, many natural assets - fisheries, minerals, forests and aquifers - are both finite and of key importance, but they are effectively 'unowned', unvalued, and/or unmarketed. Valuable natural resources are too easily seized by elites and contribute little to the national economy. Institutional change is thus at least as important as technological change (URI 2005).

Institutional change, to enable environmental management for pro-poor growth, has begun but may need scaling up. Progress has often been the result of changes in who controls the allocation and use of environmental assets, as well as better incorporation of environmental norms and incentives in mainstream institutions (Bass et al. 2005). It is remarkable how many institutional innovations have begun in Asia.

But there is scope for further governance and institutional changes to:

- improve poor people's access and rights to natural resources

- develop information, analysis and political capabilities to challenge those sectors that affect the environment most, including watchdogs

- empower poor people and local organisations to lead action on the ground

- form institutions and partnerships that link development and environment more closely - in debate, in planning, in accounting and in investment

Investment in environmental management is good for economic growth, good for quality of life and good for the quality of the global commons.

'Investments into renewables and energy efficiency technologies ... are the best hedge against the economic risks of rising oil prices and declining reserves', says the Chief Executive of the Chinese investment banking specialists, London Asia Capital (The Observer 2005). As well as reducing risk, environmental investments can produce high rates of return. An extensive global review has revealed some very persuasive figures. ${ }^{4}$ In Thailand, more than 600 firms participating in an eco-efficiency investment programme achieved an aggregate 47 per cent rate of return (ADB 2005). In China, one of the world's largest land management investments, in the Loess Plateau, has improved the livelihoods of over 1.2 million farmers: combined with other initiatives, numbers living under the poverty line halved from 59 per cent in 1993 to 27 per cent in 2001 (Zhen Liu 2004). 
There is scope for increased public investment on environmental management. The Chinese government's environmental investment is set to increase from 1.3 per cent during 2001-2005 (based on China's Tenth Five-Year Plan: 2001-2005), to 1.5 per cent (based on China's Eleventh Five-Year Plan: 2006-2010). In most other countries, though, public investment in the environment remains low, at 0.3 per cent of GDP in Indonesia, Malaysia, the Philippines, Thailand, Malaysia and Vietnam. The private sector will under-supply environmental services unless market and regulatory incentives are compelling. Investment by the public sector is often important for leveraging much larger private investment. For example, China's State Environmental Protection Agency has only 300 fulltime staff members, but without their effective strengthening and enforcement - including the means to value environmental assets and allocate appropriate funds - the private sector will be slow to invest in clean technology (Time Magazine 2004).

Private sector environment investment requires an enabling context. There is a growing body of experience on introducing environmental fiscal reform (to reduce overuse of scarce, inefficiently priced resources, such as water) and payments for environmental services (to reward those who protect, e.g. biodiversity and watersheds) (Pearce 2005). In essence, environmental 'bads' can be taxed, and environmental 'goods' supported, especially where they are pro-poor. Transaction costs can be reduced to help SMEs to benefit from environmental markets. Micro-credit can help, enabling poor households to bear the risks of investing in environmental assets.

International partnerships can provide important support to Asian countries' management of the environment for pro-poor growth. Many Asian countries are taking a lead in improving management of environmental assets, as described above. Their development partners can also play a key role. Development assistance to Asia could help 'mainstream' environment within partner governments' poverty reduction strategies or equivalent national and local planning processes, budget support, sector-wide programmes and projects. Specific initiatives could be supported that help improve the capacity of Asian authorities to manage the environment. Together, Asian countries and development partners can share technology and knowledge, catalyse environmental investment and forge institutional change in a number of priority areas. There are knowledge challenges in all the following suggested partnerships. Asian scientists and their colleagues from other regions need to play a key role in them, particularly to invigorate regional and national innovation systems. There are also institutional and investment challenges - and it is important for them to build on existing Asian-led processes:

- Healthy Asia, healthy environment: Environmental health improvements in air and water pollution can lead to major reductions in mortality. Improvements in water quality and quantity also lead to significant health benefits. ${ }^{5}$ There are a number of promising public-private partnerships across the region to increase access to clean water and air.

- Transition to sustainable energy, and tackling climate change: A meaningful post-Kyoto regime is now within reach to limit the causes and effects of climate change. Global carbon trade needs to develop in ways that support investment in clean energy (through, e.g. the Clean Development Mechanism as well as bilateral arrangements). There are good potentials for partnerships within the region on clean energy, e.g. hydropower from Nepal and Bhutan, which could also form the hub of regional energy strategies - but these would have to be planned to minimise environmental risks. There is a strong need for partnerships to improve learning, innovation and investment in adapting to climate change. The G8 Gleneagles Plan of Action highlighted many such areas for partnership, and energy will be the theme of the next G8 assembly.

- Sustainable forestry and eradicating illegal logging: Illegal logging costs countries billions of dollars in lost revenue, and harms poor people. The Asian Forest Law Enforcement and Governance initiative (AFLEG) addresses supply- and demandside incentives for illegal logging, and assures wood is traded from legal sources alone. This process serves as a high-profile means to encourage radical institutional change. It may be usefully supplemented with efforts to encourage Asian consumers to discriminate in favour of good environmental practice, and fair trade, through certification.

- Sustainable fishing: Given the importance of both fish production and fish consumption in Asia, 
improved management is vital. One innovative approach is fisheries certification, which is now beginning - but only covers 4 per cent of the world's catch. Without such approaches, the long-term future of Asia's fish producers is threatened.

- Asian rivers management: Transboundary rivers pose a major challenge: they are critical assets for growth in the countries that share them, but without effective cooperation, the environmental services they offer will be undermined. Where means for cooperation are secured such as in the Indus River Treaty and Mekong River Commission, they provide a powerful vehicle for larger regional cooperation. There is scope to strengthen work in these established forums and to extend such approaches to other basins in the region.

- Greening Asia's financial markets and private sector: Asia's private sector is booming and interest in environmental management is growing. This can be stimulated through the commercial and investment banking sectors, export markets and private sector accreditation. The Organisation for Economic Co-operation and Development (OECD) markets are vital for Asian exports and can provide important incentives for environmental improvements.

\section{Notes}

* We acknowledge valuable comments from DFID colleagues, coordinated by Leo Horn and Yvan Biot, John Humphrey of IDS, Jan Bojo and Kirk Hamilton of the World Bank and David McCauley and Nessim Ahmad of the Asian Development Bank.

1 Pakistan Participatory Poverty Assessment (2003), www.opml.co.uk/docs/1_Pakistan_PPA_national_ report.pdf

2 Over 40 per cent of Bhutan's government revenues come from hydropower exports to India.

3 The energy used by China's economy makes it the second biggest emitter of greenhouse gases. It is likely that, as the world economy's preferred
- Disaster preparedness and risk reduction: The deaths of over 70,000 in the South Asian earthquake and of over 280,000 in the Tsunami have brought home once again the vulnerability of Asia to disasters. Two things stand out: typically, it is the poor who suffer most and, with climate change, the risk of extreme weather events is increasing. Disaster preparedness requires strengthening the existing coping strategies of the poor combined with good information systems and appropriate technical, financial and physical support. The response to the 2004 Asian Tsunami and 2005 South Asia Earthquake illustrated the strengths of (as well as the challenges of managing) multiple national-international partnerships, including with the UN and the military.

- Pro-poor conservation: Since Asia has already invested over 7 per cent of its land in protected areas, there is an urgent need to both demonstrate and secure their potential contributions to pro-poor growth. One approach is for development partners to capitalise local environmental conservation and nature tourism funds that can trigger larger environmental investments.

location for heavy industries continues to shift to Asia, the focus of emissions will move with it.

4 Some 400 cases of pro-poor environmental investment revealed cost:benefit ratios of up to 14:1 for investment in water and sanitation, 4:1 for soil conservation, 5:1 for reef conservation, 7:1 for mangrove conservation and 7:1 for natural disaster prevention (Pearce 2005).

5 Asia's prospects for meeting the sanitation target of the Millennium Goal 7 (Environment) by 2015 are poor - in India alone, for instance, only 30-40 per cent of the urban population is currently linked to sanitation systems. Rural sanitation coverage is especially low. 


\section{References}

ADB (2005) Asian Environment Outlook, Manila: Asian Development Bank

Bass, S., Reid, H., Satterthwaite, D. and Steele, P. (eds) (2005) Reducing Poverty and Sustaining the Environment, The Politics of Local Engagement, London: Earthscan

Briones, M., Dey, M.M. and Ahmed, M. (2004) 'The Future of Fish in the Food and Livelihoods of the Poor in Asia', NAGA WorldFish Center Quarterly 27.3 and 4: July-December, www.worldfishcentre.org/ demandsupply

DAC/ENVIRONET Task Team and Poverty Environment Partnership on Pro-poor Growth and Natural Resources (2005) 'Sustaining ProPoor Growth or Boom and Bust? The Politics of Natural Resources', revised draft, October

Das Gupta, S., Huq, M., Khaliquzzmam, M., Pandey, K. and Wheeler, D. (2004) Who Suffers from Indoor Air Pollution? Evidence from Bangladesh, World Bank Policy Research Working Paper 3428, October

DFID (2004) Climate Change and Poverty: Making Development Resilient to Climate Change, London: Department for International Development

DFID/EC/UNDP/World Bank (2002) Linking Poverty Reduction and Environmental Management, Bangkok

Environics International (2002) International Environmental Monitor: Global Public Opinion on Environmental and Resource Issues, Toronto: Environics International

ESCAP (Economic and Social Commission for Asia and the Pacific) (2005) Report of the 5th Ministerial Conference on Environment and Development in Asia and the Pacific, Seoul 28-29 March, ECOSOCE/ESCAP/MCED/(05)/Rep

FAO (2004) Towards a Food-secure Asia and Pacific: Regional Strategic Framework, Bangkok: Food and Agriculture Organization Asia Pacific Regional Office

Far Eastern Economic Review (1990) 'Kicking up a Stink, South Korean Government Suffers from Anti-pollution Backlash', 18 October

Ford Foundation (1998) Forestry for Sustainable Rural Development: A Review of Ford Foundation Supported Community Forest Projects in Asia, New York: Ford Foundation

Jodha, N.S. (1990) 'Rural Common Property Resources: Contributions and Crisis', Economic and Political Weekly, 30 June: A65-A78

Mayers, J. and Vermeulen, S. (2001) Companycommunity Forestry Partnerships: From Raw Deal to
Mutual Gains? London: International Institute for Environment and Development (IIED)

Millennium Ecosystem Assessment (MEA) (2005) Millennium Ecosystem Assessment, www. millenniumassessment.org/en/index.aspx The Observer (4 December 2005) 'Bank Invests in Clean Air for China', Heather Connon, London

OECD (Organisation for Economic Co-operation and Development) (2004) Mainstreaming Climate Responses in Development, Issues Paper, Paris: Environment Directorate

Pearce, D. (2005) Investing in Environmental Wealth for Poverty Reduction, New York: United Nations Development Programme

Ramirez, L. (2005) 'Water Shortages are Potential Threat to China's Growth, Stability', Voice of America, 18 March, www.voanews.com/english/ archive/2005-03/2005-03-18-voa41.cfm

Roy, A.D. and Shah, T. (2002) Socio-ecology of Groundwater Irrigation in India, IWMI-TATA, International Water Management Institute, www.iumi.org/iumi-tata

Thailand Environment Monitor (2004) Ministry of Natural Resources and Environment and World Bank

Time Magazine (13 December 2004) 'Bad Air Days': $17-23$

UNEP (2004) 'An Overview of Our Changing Environment', GEO Year Book 2004/5, Nairobi: United Nations Environment Programme

UNEP (2002) Global Environmental Outlook 3, Nairobi: United Nations Environment Programme United Nations Secretariat (2002/3) 'Population Division of the Department of Economic and Social Affairs', World Population Prospects: The 2002 Revision and World Urbanization Prospects: The 2003 Revision, http://esa.un.org/unup

World Bank (2005a) Environment Strategy for the World Bank in the East Asia and Pacific Region, Washington DC: World Bank

World Bank (2005b) Little Green Data Book 2005, Washington DC: World Bank

WRI (2005) The Wealth of the Poor, Managing Ecosystems to Fight Poverty, Washington, DC: United Nations Development Programme, United Nations Environment Programme, World Bank, World Resources Institute

Zhen Liu (2004) 'China: the Loess Plateau Watershed Rehabilitation Project', paper for the World Bank, Shanghai Conference on Poverty Reduction 